\title{
Synthesis of Degradable Polyesters Having Pendant Ester Groups by Ring-Opening Polymerization of 4-Substituted 2,6-Dioxabicyclo[2.2.2] octan-3-one Derivatives
}

\author{
Miharu Atsumi $^{\dagger}$ and Masahiko OKADA ${ }^{\dagger \dagger}$ \\ Faculty of Agriculture, Nagoya University, \\ Chikusa, Nagoya 464-01, Japan
}

(Received April 17, 1992)

\begin{abstract}
New polyesters (8-10) containing tetrahydropyran rings in their backbone chains and ester groups in the side chains were synthesized by cationic ring-opening polymerization of 4-substituted 2,6-dioxabicyclo[2.2.2]octan-3-one derivatives (5-7) by using boron trifluoride etherate as an initiator in dichloromethane at $-60^{\circ} \mathrm{C}$. The polyesters $8-10$ having number average molecular weights up to $3.8 \times 10^{4}$ were soluble in a variety of solvents including benzene, tetrahydrofuran, acetone, and dimethyl sulfoxide in which the parent polyester (2) without pendant ester groups was insoluble. The polyesters 8 and $\mathbf{9}$ containing hydrophilic oxyethylene moieties in the side chains swelled in methanol, and $\mathbf{9}$ swelled even in water. Thin films of these polyesters underwent spontaneous hydrolysis in a neutral phosphate buffer solution $(\mathrm{pH} 7.5)$ at $30^{\circ} \mathrm{C}$. The apparent rate of the heterogeneous hydrolysis was markedly dependent upon the hydrophilicity of the polyesters, increasing in the order of $10<4 \approx 2<8<9$.

KEY WORDS Polyester / Ring-Opening Polymerization / Cationic Polymerization / Bicyclic Lactone / Hydrolysis / Substituent Effect / Degradability /
\end{abstract}

Environmental pollution by wasted synthetic polymeric materials is nowadays one of the most serious ecological problems, because they are not spontaneously degraded in environment. Therefore, it is urgently needed to develop "environmentally friendly" biodegradable polymers which can be substituted for conventional polymeric materials. Among the biodegradable polymers so far investigated, $\operatorname{poly}(\beta$-hydroxybutyrate) and related aliphatic polyesters produced by microorganisms are most adequate, ${ }^{1-4}$ and they are commercially produced in recent years. Meanwhile, some synthetic polyesters which are enzymatically hydrolyzable have been developed and their properties including biodegradabilities have been evaluated for practical application. ${ }^{5-9}$
Several years ago, we synthesized high molecular weight polyesters, poly(tetrahydropyran-5,2-diyloxycarbonyl) $2\left(M_{n} 1.1 \times 10^{5}\right)$ and poly [(5-(methoxycarbonyl)tetrahydropyran-5,2-diyl)oxycarbonyl] $4\left(M_{n} 1.5 \times 10^{5}\right)$ by cationic ring-opening polymerization of 2,6dioxabicyclo[2.2.2] octan-3-one (1) and its 4-methoxycarbonyl derivative (3), respectively, under properly selected conditions. ${ }^{10,11}$ These polyesters could be cast into flexible transparent films, which were disintegrated after they had been immersed in water for a period of several weeks.

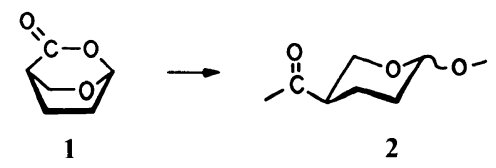

† Present address: Tokyo Woman's Christian University, Zempukuji, Suginami, Tokyo 167, Japan.

t† To whom correspondence should be addressed. 


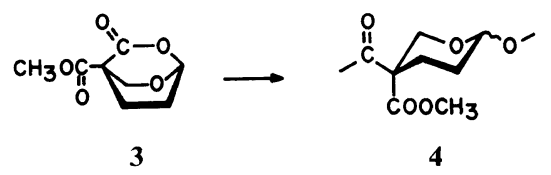

This finding encouraged us to investigate the structural factors affecting the hydrolizabilities of the polyesters of this type, since it was expected that these polyesters might be promising candidates for novel biodegradable polymeric materials. The present paper is concerned with the synthesis of the polyesters (8-10) having different ester side groups by ring-opening polymerization of 4-substituted 2,6-dioxabicyclo[2.2.2] octan-3-one derivatives (5-7) and their hydrolysis behavior in a neutral phosphate buffer solution.

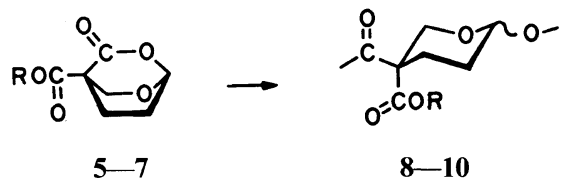

5, 8: $\mathrm{R}=\mathrm{CH}_{2} \mathrm{CH}_{2} \mathrm{OCH}_{3}$

6, 9: $\mathrm{R}=\left(\mathrm{CH}_{2} \mathrm{CH}_{2} \mathrm{O}\right)_{2} \mathrm{CH}_{3}$

7, 10: $\mathrm{R}=\mathrm{CH}_{2} \mathrm{C}_{6} \mathrm{H}_{5}$

IUPAC nomenclature: 8, poly[(5-(3-oxabutoxycarbonyl)tetrahydropyran-5,2-diyl)oxycarbonyl]; 9, poly[(5(3,6-dioxaheptoxycarbonyl)tetrahydropyran-5,2-diyl)oxycarbonyl]; 10, poly[(5-(benzyloxycarbonyl)tetrahydropyran-5,2-diyl)oxycarbonyl].

\section{RESULTS AND DISCUSSION}

\section{Monomer Synthesis}

The 4-substituted 2,6-dioxabicyclo[2.2.2]octane-3-one derivatives 5-7 were synthesized from acrolein and dimethyl malonate by a route similar to that for the synthesis of the parent compound 1. ${ }^{10}$ Scheme 1 illustrates the synthetic route for the bicyclic lactones 5-7.

The synthesis of the intermediate dimethyl 6-methoxytetrahydropyran-3,3-dicarboxylate (11) from the starting materials has been described previously. ${ }^{10-12}$ The diester 11 was saponified in ethylene glycol monomethyl ether, diethylene glycol monomethyl ether, or benzyl alcohol with an equimolar amount of

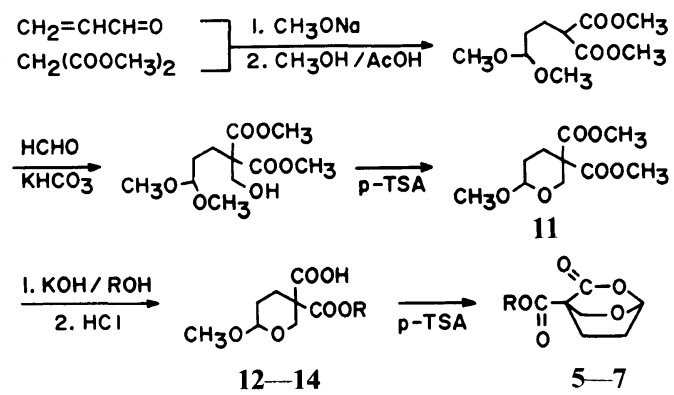

5, 12: $\mathrm{R}=\mathrm{CH}_{2} \mathrm{CH}_{2} \mathrm{OCH}_{3}$

6, 13: $\mathrm{R}=\left(\mathrm{CH}_{2} \mathrm{CH}_{2} \mathrm{O}\right)_{2} \mathrm{CH}_{3}$

7, 14: $\mathrm{R}=\mathrm{CH}_{2} \mathrm{C}_{6} \mathrm{H}_{5}$

Scheme 1. Synthetic route for 4-substituted 2,6-dioxabicyclo[2.2.2] octan-3-one derivatives (5-7).

potassium hydroxide. Transesterification took place during the saponification, and subsequent neutralization of the reaction products with hydrochloric acid gave the monoesters 12-14, respectively. They were intramolecularly cyclized in a refluxing dilute toluene solution in the presence of a catalytic amount of $p$ toluenesulfonic acid to yield the corresponding bicyclic lactones 5-7.

\section{Polymerization}

Cationic polymerization of the bicyclic lactones 5-7 was carried out in dichloromethane at $-60^{\circ} \mathrm{C}$. Boron trifluoride etherate was used as an initiator. The results are listed in Table I, together with the representative data for the polymerization of $\mathbf{1}$ and $\mathbf{3}$ for comparison.

In all the cases, polyesters having number average molecular weights above $1 \times 10^{4}$ were formed. However, the polymerization of 5-7 was considerably slower than that of 3 . The apparently lower polymerizabilities of $\mathbf{5}$ and $\mathbf{6}$, particularly the latter, clearly arise from the nucleophilic oxyethylene moieties in the monomers and their polymers: These moieties compete with the lactone rings of the monomers in interacting with cationic species to reduce the fraction of the cationic species participating in the initiation and propagation. The bicyclic lactone 7 having a benzyl ester 
Table I. Polymerization of 2,6-dioxabicycl[2.2.2]octan-3-one (1) and its derivatives $(3 \text { and } 5-7)^{\mathrm{a}}$

\begin{tabular}{|c|c|c|c|c|c|c|}
\hline Monomer & $\frac{[\mathrm{M}]}{\mathrm{moll}^{-1}}$ & $\frac{\mathrm{BF}_{3} \mathrm{OEt}_{2}}{\mathrm{~mol} \%}$ & $\frac{\text { Time }}{\mathrm{h}}$ & $\frac{\text { Yield }^{\mathrm{b}}}{\%}$ & cis: trans $^{\mathrm{c}}$ & $\begin{array}{c}M_{\mathrm{n}}^{\mathrm{d}} \\
\times 10^{-4}\end{array}$ \\
\hline $1^{10}$ & 1.7 & 3 & 0.25 & 95 & $33: 67$ & $11^{\mathrm{e}}$ \\
\hline $3^{11}$ & 0.6 & 2 & 1 & 73 & $37: 63$ & 5.6 \\
\hline 5 & 1.0 & 5 & 24 & 90 & $43: 57$ & 1.3 \\
\hline 5 & 2.5 & 2 & 24 & 93 & $41: 59$ & 1.5 \\
\hline 6 & 1.0 & 5 & 48 & 55 & $54: 46$ & 1.8 \\
\hline 7 & 1.0 & 5 & 17 & 95 & $30: 70$ & 3.8 \\
\hline
\end{tabular}

a Solvent, dichloromethane; temp, $-60^{\circ} \mathrm{C}$.

b Methanol insoluble polymer.

c Determined by ${ }^{1} \mathrm{H}$ NMR spectroscopy.

d Determined by VPO.

e Determined by GPC (polystyrene standard).

Table II. Solubilities of the polyesters $(2,4 \text {, and } 8-10)^{a}$

\begin{tabular}{|c|c|c|c|c|c|}
\hline \multirow{2}{*}{ Solvent } & \multicolumn{5}{|c|}{ Polyester } \\
\hline & 2 & 4 & 8 & 9 & 10 \\
\hline Benzene & ( & ( & 0 & 0 & 0 \\
\hline Dichloromethane & 0 & 0 & 0 & 0 & 0 \\
\hline Tetrahydrofuran & ( & 0 & 0 & 0 & 0 \\
\hline Acetone & ( & 0 & 0 & 0 & 0 \\
\hline Dimethyl sulfoxide & ( & 0 & 0 & 0 & 0 \\
\hline Dimethylformamide & 0 & 0 & 0 & 0 & 0 \\
\hline Ethyl acetate & 0 & 1 & $\mathrm{O}$ & $\mathrm{O}$ & 0 \\
\hline Acetonitrile & 0 & 0 & 0 & 0 & (1) \\
\hline Dioxane & 0 & 0 & 0 & $\mathrm{O}$ & (1) \\
\hline Ethyl ether & 0 & 0 & (1) & ( & \\
\hline Methanol & 0 & 0 & 0 & ( & 0 \\
\hline Water & 0 & 0 & & ( & \\
\hline
\end{tabular}

a At room temperature.

O, soluble; $\mathbf{O}$, swollen; $\mathbf{O}$, insoluble.

group was also less reactive than 3 . This is presumably due to the steric hindrance by the bulky benzyloxycarbonyl group and to the reduced nucleophilicity of the lactone ring as well.

Table II summarizes the solubilities of a series of the polyesters consisting of 2,5-linked tetrahydropyran rings. The polyesters 8 and 9 having oxyethylene moieties in their side chains were soluble in a variety of solvents including

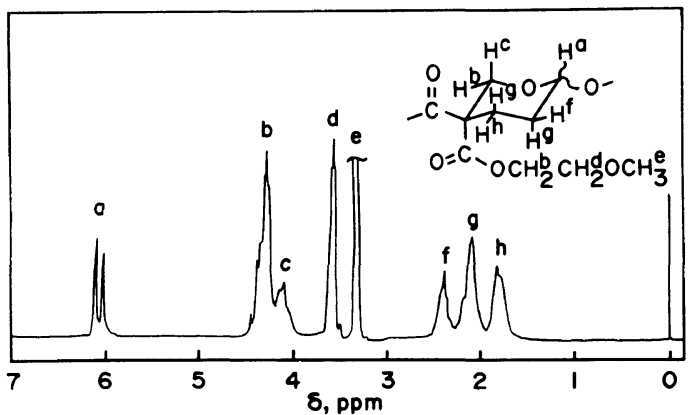

Figure 1. ${ }^{1} \mathrm{H}$ NMR spectrum of poly(5-(methoxyethoxycarbonyl)tetrahydropyran-5,2-diyloxycarbonyl) (8) prepared in dichloromethane at $-60^{\circ} \mathrm{C}$ with $\mathrm{BF}_{3} \mathrm{OEt}_{2}$ as the initiator (solv., $\mathrm{CDCl}_{3}$; room temperature; TMS; 200 $\mathrm{MHz}$.

benzene, dichloromethane, tetrahydrofuran, ethyl acetate, acetone, acetonitrile, and dimethyl sulfoxide. These polyesters swelled in methanol, and in particular, 9 swelled even in water. Clearly, the introduction of the oxyethylene moieties in the side chains remarkably enhanced the hydrophilicity of the polyesters. The polyester $\mathbf{1 0}$ with pendant benzyloxycarbonyl groups also dissolved in various organic solvents.

Figure 1 presents the ${ }^{1} \mathrm{H}$ NMR spectrum of the polyester $\mathbf{8}$. The signals a assignable to the anomeric methine proton $\mathrm{H}^{\mathrm{a}}$ appears as a pair 


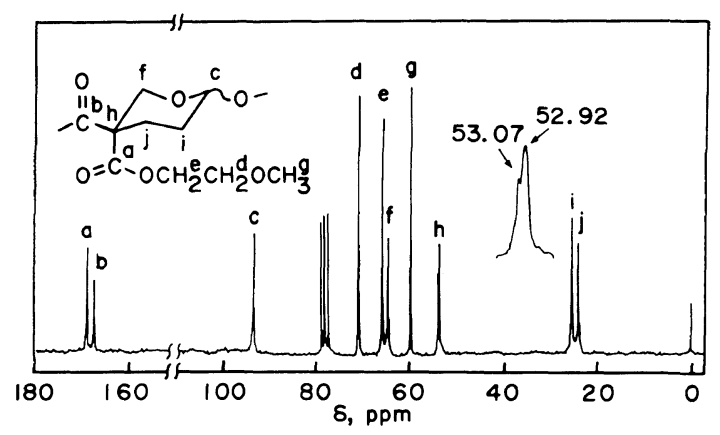

Figure 2. ${ }^{13} \mathrm{C}$ NMR spectrum of poly(5-(methoxyethoxycarbonyl)tetrahydropyran-5,2-diyloxycarbonyl) (8) prepared in dichloromethane at $-60 \mathrm{C}$ with $\mathrm{BF}_{3} \mathrm{OEt}_{2}$ as the initiator (solv., $\mathrm{CDCl}_{3}$; room temperature; TMS; 200 $\mathrm{MHz}$ ).

of peaks with different intensities at $\delta 6.10$ and 6.01 , indicating the presence of structurally different units in the polymer chain, that is, trans- and cis-2,5-linked tetrahydropyran units. On the basis of the ${ }^{1} \mathrm{H}$ NMR spectral data previously reported for the 4-methoxycarbonyl derivative $4,{ }^{11}$ the peaks a at $\delta 6.10$ and 6.01 were assigned to the anomeric methine protons $\mathrm{H}^{\mathrm{a}}$ in the trans- and cis-structural units, respectively. The ${ }^{1} \mathrm{H}$ NMR spectral data for the polyesters $\mathbf{8 - 1 0}$ are given in the Experimental section.

Figure 2 shows the ${ }^{13} \mathrm{C}$ NMR spectrum of the polyester $\mathbf{8}$. The signals due to the trans-and cis-structural units are not clearly differentiated in the $50 \mathrm{MHz}{ }^{13} \mathrm{C} \mathrm{NMR}$ spectrum. Only the signal $h$ due to the quarternary carbon is discernible as the overlapped peaks with slightly different chemical shifts as demonstrated in the expanded spectrum. This is obviously due to the structurally close resemblance of the stable conformers of the cis- and trans-structural units. The ${ }^{13} \mathrm{C}$ NMR data for the polyesters $8-\mathbf{1 0}$ are summarized in the Experimental section.

The ${ }^{1} \mathrm{H}$ and ${ }^{13} \mathrm{C}$ NMR spectral data indicated that all these polyesters were composed of the cis- and trans-2,5-linked tetrahydropyran rings. The proportions of the cis- and trans-structural units estimated from the relative peak areas of the anomeric methine proton signals a are listed in Table I. The conformational energy estimation of the two conformers for both the cis- and transstructural units suggest that the conformational equilibrium lies on the left side in each case. $^{11}$

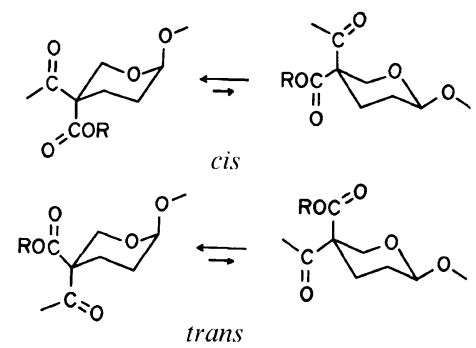

\section{Hydrolysis of the Polyesters}

Thin films of the structurally related polyesters 2, 4, and $\mathbf{8}-\mathbf{1 0}$ were immersed in a neutral phosphate buffer solution $(\mathrm{pH}, 7.5)$ at $30^{\circ} \mathrm{C}$. The spontaneous hydrolysis of the films was monitored by the measurements of the weights of the water-insoluble residues and their molecular weights.

Figure 3 demonstrates the decrease in the weights of the water-insoluble residues as a function of the immersion time in the heterogeneous hydrolysis. The polyester $\mathbf{8}$ and 9 with hydrophilic oxyethylene moieties in the side chains were hydrolyzed faster than the other polyesters 2, 4, and 10. Particularly, the polyester 9 which swelled in water was nearly completely hydrolyzed within five days. In contrast, the polyester $\mathbf{1 0}$ having hydrophobic benzyl groups in the side chains was hydrolyzed very slowly; about $90 \mathrm{wt} \%$ of the original sample remained water-insoluble after 20 days.

The hydrolysis of the hydrophobic polyesters $\mathbf{2 , 4}$, and 10 presumably occurs mainly on the surface of the films, whereas the hydrolysis of the hydrophilic polyesters $\mathbf{8}$ and $\mathbf{9}$ takes place not only on the surface but also in the inner part of the films. Especially, for the polyester 9 which swells in water, the hydrolysis in the inner part of the film must proceed faster than 


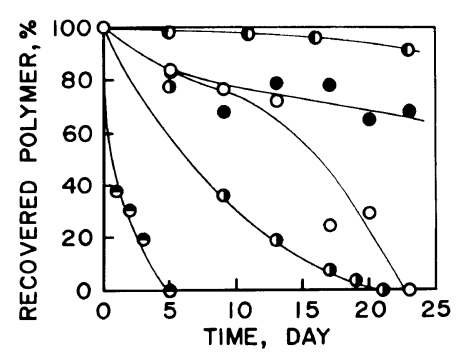

Figure 3. Heterogeneous hydrolysis of the polyesters containing tetrahydropyran rings in their main chains. Polymer, $20 \mathrm{mg}$; phosphate buffer (pH 7.5), $5 \mathrm{ml}$; temp, $30^{\circ} \mathrm{C}$. $\bigcirc, 2 ; \boldsymbol{O}, 4 ; \boldsymbol{\top}, 8 ; \ominus, 9 ; \boldsymbol{D}, 10$.

any other polyesters.

The hydrolysis of $\mathbf{2}$ proceeded as slowly as that of $\mathbf{4}$ in the early stage. However, after about 15 days, the originally transparent film became turbid and thereafter it was rapidly hydrolyzed. Such hydrolysis behavior was found reproducible.

Figure 4 shows the decrease in the number-avarage molecular weights of the polyesters with the time of immersion in the buffer solution. For all the polyesters examined, rapid depression in the molecular weight was observed at the beginning of the hydrolysis, followed by gradual decrease. This phenomenon implies that the polymer chains do not depolymerize from the terminal units but they are cleaved randomly.

The decrease in the molecular weights of the water-insoluble residues was not necessarily parallel with the decrease in their weights. In the heterogeneous hydrolysis examined here, the weights of water-insoluble residues and their molecular weights should depend not only on the rate of hydrolysis but also on the solubility in water of the oligomers formed in the hydrolysis. Thus, the polyesters 8 and $\mathbf{9}$ having the oxyethylene moieties in their side chains are hydrophilic, and therefore, it is very likely that their oligomers of relatively low molecular weights are water-soluble. On the other hand, the polyesters 2, 4, and $\mathbf{1 0}$ are hydrophobic and hence, even the oligomers of considerably low molecular weights must be

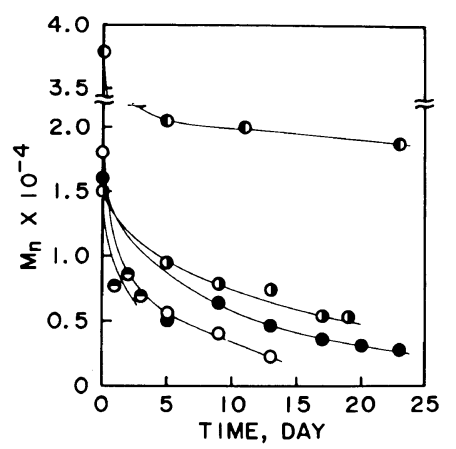

Figure 4. Changes in the molecular weights of polyesters with time in the heterogeneous hydrolysis. Polymer, $20 \mathrm{mg}$; phosphate buffer (pH 7.5), $5 \mathrm{ml}$; temp, $30^{\circ} \mathrm{C}$. $\bigcirc, 2 ; \mathbf{O}, 4$; ๑, $8 ; \ominus, 9 ; \boldsymbol{D}, 10$.

insoluble in water.

In the hydrolysis of $\mathbf{2}$, the water-insoluble residues became insoluble in chloroform in which the original polyester 2 was soluble, after the immersion in the buffer solution for 15 days. According to the ${ }^{1} \mathrm{H}$ NMR analysis, the water-insoluble residues were mainly composed of the low molecular weight oligomers with the number average degree of polymerization of $3-4$. This means that the concentrations of the polar hydroxyl and carboxyl end groups are relatively high, so that the oligomers become less hydrophobic. In other words, water molecules are more readily accessible to the backbone chains, and therefore, the hydrolysis is accelerated, as described before.

Water-soluble oligomers were not isolated from a supernatant solution for any polyester. Instead, only the corresponding 5-hydroxytetrahydropyran-2-carboxylic acids were detected in most cases. Probably, the watersoluble oligomers formed in the hydrolysis were more rapidly hydrolyzed in a homogeneous solution, eventually giving the respective hydroxycarboxylic acids $15-19$. This finding supports that the spontaneous hydrolysis occurs exclusively on the acetal-ester linkages in the main chains, whereas hydrolysis on the pendant ester groups, if any, is negligible. 


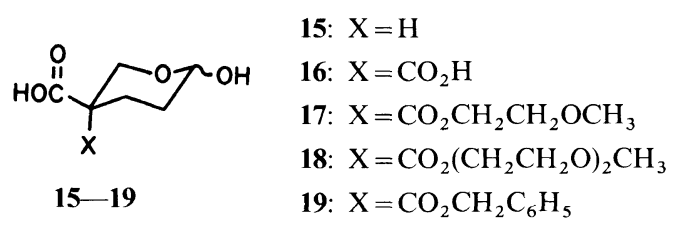

In conclusion, all the polyesters $\mathbf{2 , 4}$, and 8-10 undergo spontaneous hydrolysis in a neutral phosphate buffer solution $(\mathrm{pH} 7.5)$ at ambient temperature. This property is most probably ascribable to their main chain structure containing acetal-ester linkages. The observed difference in the apparent hydrolysis rate seems to be primarily related to the hydrophilicity of these polyesters $(\mathbf{1 0}<\mathbf{4} \approx \mathbf{2}<$ $\mathbf{8}<\mathbf{9}$ ). Finally, it is noteworthy that a film of 2 was nearly completely degraded within 50 days on a preliminary soil burial test.

\section{EXPERIMENTAL}

\section{General Methods}

${ }^{1} \mathrm{H}$ and ${ }^{13} \mathrm{C}$ NMR spectra were recorded on a JEOL JMN FX-200 spectrometer operating at $200\left({ }^{1} \mathrm{H}\right)$ and $50 \mathrm{MHz}\left({ }^{13} \mathrm{C}\right)$, respectively. Deuteriochloroform and tetramethylsilane were as solvent and internal reference. IR spectra were measured with a JASCO A-3 spectrophotometer. Molecular weights of the polymers were determined by using a Corona Electric M-117 vapor pressure osmometer (solvent, benzene or chloroform).

Preparation of Methoxyethoxy Hydrogen 6Methoxytetrahydropyran-3,3-dicarboxylate (12)

Dimethyl 6-methoxytetrahydropyran-3,3dicarboxylate (11) was synthesized from acrolein and dimethyl malonate according to the procedures reported previously. ${ }^{10-12} \mathrm{~A}$ solution of potassium hydroxide $(2.79 \mathrm{~g}$, $42.3 \mathrm{mmol})$ in ethylene glycol monomethyl ether $(75 \mathrm{ml})$ was slowly added to a solution of the diester $11(9.64 \mathrm{~g}, 41.6 \mathrm{mmol})$ in ethylene glycol monomethyl ether $(50 \mathrm{ml})$ at room temperature. The reaction mixture was allowed to stand overnight at room temperature and then subjected to rotary evaporation. The residue was dissolved in $50 \mathrm{ml}$ of water, followed by extraction with three $20 \mathrm{ml}$ portions of diethyl ether to remove the diester. The aqueous layer was neutralized with $6 \mathrm{~N}$ hydrochloric acid and extracted with three $50 \mathrm{ml}$ portions of diethyl ether. The combined ether extracts were washed with saturated aqueous solution of sodium chloride and dried over anhydrous magnesium sulfate. Rotary evaporation of the solvent gave $\mathbf{1 2}$ as a viscous oil: yield $88 \% ;{ }^{1} \mathrm{H}$ NMR $\left(\mathrm{CDCl}_{3}\right) \delta 6.8-7.3$ (br, $\mathrm{COOH}$ ), $4.50-4.72$ (m, 1H, H-6), 4.26$4.52\left(\mathrm{~m}, 2 \mathrm{H}, \mathrm{COOCH}_{2}\right), 4.02-4.30(\mathrm{~m}, 2 \mathrm{H}$, $2 \mathrm{H}-2), 3.45-3.90\left(\mathrm{~m}, 2 \mathrm{H}, \mathrm{CH}_{2} \mathrm{OCH}_{3}\right), 3.40$ (s, 6H, $\mathrm{CHOC}_{3}$ and $\left.\mathrm{CH}_{2} \mathrm{OC}_{3}\right), 1.6-2.3$ ppm (m, 4H, 2H-4 and $2 \mathrm{H}-5) ;{ }^{13} \mathrm{C}$ NMR $\left(\mathrm{CDCl}_{3}\right) \delta 173.04(\mathrm{COOH}), 169.24(\mathrm{C}=\mathrm{O}$, ester), 98.39 (C-6), $70.07\left(\mathrm{C}_{2} \mathrm{OCH}_{3}\right), 65.52$ $\left(\mathrm{COOCH}_{2}\right), 62.38(\mathrm{C}-2), 58.82\left(\mathrm{CH}_{2} \mathrm{OCH}_{3}\right)$, $55.11\left(\mathrm{CHOCH}_{3}\right), 53.36(\mathrm{C}-3), 26.51$ (C-5), $24.41 \mathrm{ppm}(\mathrm{C}-4)$.

Preparation of (Methoxyethoxy)ethoxy Hydrogen 6-Methoxytetrahydropyran-3,3-dicarboxylate (13)

A solution of potassium hydroxide $(2.60 \mathrm{~g}$, $39.4 \mathrm{mmol}$ ) in diethylene glycol monomethyl ether $(20 \mathrm{ml})$ was slowly added to a solution of the diester $11(8.89 \mathrm{~g}, 38.3 \mathrm{mmol})$ in diethylene glycol monomethyl ether $(30 \mathrm{ml})$ at room temperature. The reaction mixture was allowed to stand for 3 days at room temperature. It was worked up as described above. Yield $75 \%$; ${ }^{1} \mathrm{H}$ NMR $\left(\mathrm{CDCl}_{3}\right) \delta 6.1-6.6$ (br, $\left.\mathrm{COOH}\right)$, $4.50-4.72(\mathrm{~m}, 1 \mathrm{H}, \mathrm{H}-6), 4.26-4.52(\mathrm{~m}, 2 \mathrm{H}$, $\left.\mathrm{COOCH}_{2}\right), 4.02-4.30(\mathrm{~m}, 2 \mathrm{H}, 2 \mathrm{H}-2), 3.45-$ $3.90\left(\mathrm{~m}, 6 \mathrm{H}, \mathrm{C}_{2} \mathrm{OCH}_{2} \mathrm{C}_{2} \mathrm{OCH}_{3}\right), 3.40(\mathrm{~s}$, $\left.6 \mathrm{H}, \mathrm{CHOC}_{3}, \mathrm{CH}_{2} \mathrm{OCH}_{3}\right), 1.6-2.3 \mathrm{ppm}(\mathrm{m}$, $4 \mathrm{H}, 2 \mathrm{H}-4$ and $2 \mathrm{H}-5) ;{ }^{13} \mathrm{C} \mathrm{NMR}\left(\mathrm{CDCl}_{3}\right) \delta$ $172.36(\mathrm{COOH}), 169.39(\mathrm{C}=\mathrm{O}$, ester $), 98.34$ (C-6), 71.78, $70.22\left(\mathrm{C}_{2} \mathrm{CH}_{2} \mathrm{OCH}_{3}\right), 68.71$ $\left(\mathrm{COOCH}_{2} \underline{\mathrm{CH}}_{2}\right), \quad 64.61 \quad\left(\mathrm{COOC}_{2}\right), \quad 62.47$ $(\mathrm{C}-2), 58.82\left(\mathrm{CH}_{2} \mathrm{OC}_{3}\right), 55.07\left(\mathrm{CHOCH}_{3}\right)$, 53.26 (C-3), 26.51 (C-5), 24.46 ppm (C-4). 
Preparation of Benzyl Hydrogen 6-Methoxytetrahydropyran-3,3-dicarboxylate (14)

A solution of potassium hydroxide $(3.69 \mathrm{~g}$, $55.9 \mathrm{mmol})$ in benzyl alcohol $(40 \mathrm{ml})$ was slowly added to a solution of the diester $11(12.8 \mathrm{~g}$, $55.2 \mathrm{mmol})$ in benzyl alcohol $(30 \mathrm{ml})$ at room temperature. The reaction mixture was allowed to stand for 2 days at room temperature. It was worked up in a manner similar to that described for the preparation of 12 . Yield $80 \%$; ${ }^{1} \mathrm{H} \mathrm{NMR}\left(\mathrm{CDCl}_{3}\right) \delta 7.90(\mathrm{~s}, 1 \mathrm{H}, \mathrm{COOH}), 7.30$ $\left(\mathrm{s}, 5 \mathrm{H}, \mathrm{C}_{6} \mathrm{H}_{5}\right), 5.20,5.15\left(\mathrm{~s}, \mathrm{C}_{6} \mathrm{H}_{5} \mathrm{CH}_{2}\right), 4.55$ (m, 1H, H-6), $4.00-4.30(\mathrm{~m}, 2 \mathrm{H}, 2 \mathrm{H}-2), 3.34$ (s, 3H, $\left.\mathrm{OCH}_{3}\right), 1.6-2.4 \mathrm{ppm}(\mathrm{m}, 4 \mathrm{H}, 2 \mathrm{H}-4$ and $2 \mathrm{H}-5) ;{ }^{13} \mathrm{C} \mathrm{NMR}\left(\mathrm{CDCl}_{3}\right) \delta 173.61,173.46$ $(\mathrm{COOH}), 168.85,168.75(\mathrm{C}=\mathrm{O}$, ester $), 135.10$, $135.01\left(\mathrm{C}_{6} \mathrm{H}_{5}\right.$, ipso $), 128.28,128.01\left(\mathrm{C}_{6} \mathrm{H}_{5}\right.$, ortho $), 127.60,127.46\left(\mathrm{C}_{6} \mathrm{H}_{5}\right.$, meta $), 126.85$ $\left(\mathrm{C}_{6} \mathrm{H}_{5}\right.$, para $), 98.23,98.10$ (C-6), 67.24, 67.20 $\left(\mathrm{COOCH}_{2}\right), 62.34,62.20(\mathrm{C}-2), 54.98\left(\mathrm{OCH}_{3}\right)$, 53.38 (C-3), 26.43 (C-5), 24.49, $24.22 \mathrm{ppm}$ (C-4).

Preparation of 4-(Methoxyethoxy)carbonyl2,6-dioxabicyclo[2.2.2]octan-3-one (5)

A solution of $12(4.40 \mathrm{~g}, 16.7 \mathrm{mmol})$ and $p$ toluenesulfonic acid $(53 \mathrm{mg}, 0.28 \mathrm{mmol})$ in dry toluene $(400 \mathrm{ml})$ was allowed to reflux through a Soxhlet extractor for $3.5 \mathrm{~h}$. The Soxhlet thimble was charged with Type 4A molecular sieves $(30 \mathrm{~g})$. After the solution was cooled to room temperature, anhydrous potassium carbonate $(20 \mathrm{~g})$ was added to the solution and the mixture was stirred at room temperature for $1 \mathrm{~h}$. The mixture was filtered and subjected to rotary evaporation to afford a slightly brown oil. Column chromatographic separation of the residue (column, silica gel; eluent, dichloromethane-acetone, $10: 1, \mathrm{v} / \mathrm{v}$ ) gave 5 as a transparent liquid: yield, $68 \% ;{ }^{1} \mathrm{H}$ NMR $\left(\mathrm{CDCl}_{3}\right)$ $\delta 5.72$ (br s, $1 \mathrm{H}, \mathrm{H}-1), 4.42$ (dd, $1 \mathrm{H}, J=3.3$ and $9.1 \mathrm{~Hz}, \mathrm{H}-5), 4.38\left(\mathrm{~m}, 2 \mathrm{H}, \mathrm{COOCH}_{2}\right), 4.08$ (d, $1 \mathrm{H}, J=9.1 \mathrm{~Hz}, \mathrm{H}-5), 3.63\left(\mathrm{~m}, 2 \mathrm{H}, \mathrm{CH}_{2} \mathrm{OCH}_{3}\right)$, $3.38\left(\mathrm{~s}, 3 \mathrm{H}, \mathrm{OCH}_{3}\right), 2.11-2.42 \mathrm{ppm}(\mathrm{m}, 4 \mathrm{H}$, $2 \mathrm{H}-7$ and $2 \mathrm{H}-8) ;{ }^{13} \mathrm{C} \mathrm{NMR}\left(\mathrm{CDCl}_{3}\right) \delta 168.80$ $\left(\mathrm{COOCH}_{2}\right), 166.75(\mathrm{C}=\mathrm{O}$, lactone $), 97.80$
(C-1), $69.98\left(\mathrm{C}_{2} \mathrm{OCH}_{3}\right), 67.48$ (C-5), 64.90 $\left(\mathrm{COOCH}_{2}\right), 58.91\left(\mathrm{OCH}_{3}\right), 48.92(\mathrm{C}-4), 26.02$ (C-7), 23.34 ppm (C-8).

Preparation of 4-(Methoxyethoxy)ethoxycarbonyl-2,6-dioxabicyclo[2.2.2]octan-3-one (6) A solution of $13(6.90 \mathrm{~g}, 23.4 \mathrm{mmol})$ and p-toluenesulfonic acid $(126 \mathrm{mg}, 0.67 \mathrm{mmol})$ in dry toluene $(500 \mathrm{ml})$ was allowed to reflux for $9 \mathrm{~h}$ through a Soxhlet extractor with a thimble charged with Type 4A molecular sieves $(30 \mathrm{~g})$. The reaction mixture was then worked up in a manner similar to that described above. Yield, $57 \% ;{ }^{1} \mathrm{H} \mathrm{NMR}\left(\mathrm{CDCl}_{3}\right) \delta 5.72$ (br s, $\left.1 \mathrm{H}, \mathrm{H}-1\right)$, $4.42(\mathrm{dd}, 1 \mathrm{H}, J=3.3$ and $9.3 \mathrm{~Hz}, \mathrm{H}-5), 4.40(\mathrm{~m}$, $\left.2 \mathrm{H}, \mathrm{COOCH}_{2}\right), 4.08(\mathrm{~d}, 1 \mathrm{H}, J=9.3 \mathrm{~Hz}, \mathrm{H}-5)$, $3.75\left(\mathrm{~m}, 2 \mathrm{H}, \mathrm{COOCH}_{2} \mathrm{C}_{2}\right), 3.60-3.70(\mathrm{~m}$, $\left.2 \mathrm{H}, \quad \mathrm{CH}_{2} \mathrm{CH}_{2} \mathrm{OCH}_{3}\right), 3.50-3.60(\mathrm{~m}, 2 \mathrm{H}$, $\left.\mathrm{CH}_{2} \mathrm{CH}_{2} \mathrm{OCH}_{3}\right), 3.38\left(\mathrm{~s}, 3 \mathrm{H}, \mathrm{OCH}_{3}\right), 2.11-$ $2.42 \mathrm{ppm}(\mathrm{m}, 4 \mathrm{H}, 2 \mathrm{H}-7$ and $2 \mathrm{H}-8) ;{ }^{13} \mathrm{C}$ NMR $\left(\mathrm{CDCl}_{3}\right) \delta 168.94(\underline{\mathrm{COOCH}})_{2}, 166.70(\mathrm{C}=\mathrm{O}$, lactone), 97.85 (C-1), 71.83, $70.46\left(\mathrm{C}_{2} \underline{\mathrm{CH}}_{2}\right.$ $\left.\mathrm{OCH}_{3}\right), 68.66\left(\mathrm{COOCH}_{2} \mathrm{CH}_{2}\right), 67.54(\mathrm{C}-5)$, $65.01\left(\mathrm{COOCH}_{2}\right), 59.01\left(\mathrm{OCH}_{3}\right), 48.93(\mathrm{C}-4)$, 26.02 (C-7), $23.39 \mathrm{ppm}(\mathrm{C}-8)$.

Preparation of 4-Benzyloxycarbonyl-2,6-dioxabicyclo[2.2.2]octan-3-one (7)

A solution of $14(4.71 \mathrm{~g}, 15.4 \mathrm{mmol})$ and p-toluenesulfonic acid $(60 \mathrm{mg}, 0.32 \mathrm{mmol})$ in dry toluene $(450 \mathrm{ml})$ was allowed to reflux through a Soxhlet extractor for $7 \mathrm{~h}$. The Soxhlet thimble was charged with Type 4A molecular sieves $(30 \mathrm{~g})$. After the solution was cooled to room temperature, anhydrous potassium carbonate $(20 \mathrm{~g})$ was added to the solution and the mixture was stirred at room temperature for $1 \mathrm{~h}$. The mixture was filtered and subjected to rotary evaporation to afford slightly yellow oil. The residue was extracted with $n$-hexane. The $n$-hexane solution was concentrated to give a white solid; yield, $79 \%$. Recrystallization from ethyl ether gave a white crystals: $\mathrm{mp}$, $52-53^{\circ} \mathrm{C} ;{ }^{1} \mathrm{H} \mathrm{NMR}\left(\mathrm{CDCl}_{3}\right) \delta 7.44(\mathrm{~s}, 5 \mathrm{H}$, $\mathrm{C}_{6} \mathrm{H}_{5}$ ), 5.76 (brs, 1H, H-1), $5.30(\mathrm{~s}, 2 \mathrm{H}$, $\mathrm{C}_{2} \mathrm{C}_{6} \mathrm{H}_{5}$ ), 4.46 (dd, $1 \mathrm{H}, J=3.1$ and $8.9 \mathrm{~Hz}$, 
H-5), 4.08 (d, 1H, $J=8.9 \mathrm{~Hz}, \mathrm{H}-5), 2.0-2.6$ ppm (m, 4H, 2H-7, 2H-8); ${ }^{13} \mathrm{C} \mathrm{NMR}\left(\mathrm{CDCl}_{3}\right)$ $\delta 168.85\left(\mathrm{COOCH}_{2}\right), 166.66(\mathrm{C}=\mathrm{O}$, lactone $)$, $134.89\left(\mathrm{C}_{6} \mathrm{H}_{5}\right.$, ipso $), 128.55\left(\mathrm{C}_{6} \mathrm{H}_{5}\right.$, ortho $)$, $128.45\left(\mathrm{C}_{6} \mathrm{H}_{5}\right.$, meta $), 128.06\left(\mathrm{C}_{6} \mathrm{H}_{5}\right.$, para $)$, $97.80(\mathrm{C}-1), 67.63,67.48\left(\mathrm{C}-5, \mathrm{COOC}_{2}\right)$, 48.97 (C-4), 26.02 (C-7), 23.39 ppm (C-8).

\section{Polymerization}

Cationic polymerization of 5-7 was carried out in dichloromethane at $-60^{\circ} \mathrm{C}$ with boron trifluoride etherate as an initiator. A high vacuum technique was employed for the polymerization. After the polymerization was terminated by the addition of a small amount of pyridine, the reaction mixture was poured into a large volume of methanol to precipitate a polymer. It was purified by repeated reprecipitation using dichloromethane and methanol as a solvent-precipitant pair, followed by freeze-drying from a benzene solution.

8: ${ }^{1} \mathrm{H} \mathrm{NMR}\left(\mathrm{CDCl}_{3}\right) \delta 6.10$ (H-2, trans unit), 6.01 (H-2, cis unit), 3.9-4.5 (H-6, $\left.\mathrm{COOCH}_{2}\right)$, $3.50-3.70\left(\mathrm{CH}_{2} \mathrm{OCH}_{3}\right), 3.34\left(\mathrm{OCH}_{3}\right), 2.39$ $\left(\mathrm{H}-3_{\text {eq }}\right), 2.10\left(\mathrm{H}-3_{\text {ax }}\right.$ and $\left.\mathrm{H}-4_{\text {eq }}\right), 1.84$ ppm $(\mathrm{H}-$ $\left.4_{\mathrm{ax}}\right) ;{ }^{13} \mathrm{C} \mathrm{NMR}\left(\mathrm{CDCl}_{3}\right) \delta 168.36\left(\mathrm{COOCH}_{2}\right)$, $167.03(\mathrm{C}=\mathrm{O}$, main chain), $91.96(\mathrm{C}-2), 69.89$, $\left.69.77\left(\underline{\mathrm{CH}}_{2} \mathrm{OCH}_{3}\right), 64.74\left(\mathrm{COOC}_{2}\right)_{2}\right), 63.60$ (C-6), $58.75\left(\mathrm{OCH}_{3}\right), 53.07,52.92(\mathrm{C}-5), 24.91$ (C-3), 23.57 ppm (C-4).

9: ${ }^{1} \mathrm{H} \mathrm{NMR}\left(\mathrm{CDCl}_{3}\right) \delta 6.09$ ( $\mathrm{H}-2$, trans unit), $6.01\left(\mathrm{H}-2\right.$, cis unit), 3.9-4.5 $\left(\mathrm{H}-6, \mathrm{COOCH}_{2}\right)$, $3.68-3.80\left(\mathrm{COOC}_{2} \mathrm{CH}_{2}\right), 3.57-3.68\left(\mathrm{C}_{2^{-}}\right.$ $\left.\mathrm{CH}_{2} \mathrm{OCH}_{3}\right), 3.48-3.57\left(\mathrm{CH}_{2} \mathrm{CH}_{2} \mathrm{OCH}_{3}\right), 3.37$ $\left(\mathrm{OCH}_{3}\right), 2.39\left(\mathrm{H}-3_{\mathrm{eq}}\right), 2.10\left(\mathrm{H}-3_{\mathrm{ax}}\right.$ and $\left.\mathrm{H}-4_{\mathrm{eq}}\right)$, $1.78 \mathrm{ppm}\left(\mathrm{H}-4_{\mathrm{ax}}\right) ;{ }^{13} \mathrm{C} \mathrm{NMR}\left(\mathrm{CDCl}_{3}\right) \delta 168.34$ $\left(\mathrm{COOC} \mathrm{H}_{2}\right), 167.03(\mathrm{C}=\mathrm{O}$, main chain $), 91.97$ (C-2) 71.76, $70.38 \quad\left(\mathrm{CH}_{2} \underline{\mathrm{CH}}_{2} \mathrm{OCH}_{3}\right), 68.58$, $68.46\left(\mathrm{COOCH}_{2} \underline{\mathrm{CH}}_{2}\right), 64.89 \quad\left(\mathrm{COOC}_{2}\right)$, 63.68 (C-6), $58.87\left(\mathrm{OCH}_{3}\right), 53.07,52.92(\mathrm{C}-5)$, 24.93 (C-3), 23.69 ppm (C-4).

10: ${ }^{1} \mathrm{H}$ NMR $\left(\mathrm{CDCl}_{3}\right) \delta 7.29\left(\mathrm{C}_{6} \mathrm{H}_{5}\right), 6.01$ (H-2, trans unit), 5.96 (H-2, cis unit), 5.03-5.31 $\left(\mathrm{COOCH}_{2}\right), 3.96-4.30(\mathrm{H}-6), 2.30$ $\left(\mathrm{H}-3_{\mathrm{eq}}\right), 2.00\left(\mathrm{H}-3_{\mathrm{ax}}\right.$ and $\left.\mathrm{H}-4_{\mathrm{eq}}\right), 1.68 \mathrm{ppm}(\mathrm{H}-$ $\left.4_{\mathrm{ax}}\right) ;{ }^{13} \mathrm{C} \mathrm{NMR}\left(\mathrm{CDCl}_{3}\right) \delta 168.24\left(\mathrm{COOCH}_{2}\right)$, $166.98(\mathrm{C}=\mathrm{O}$, main chain), 135.03, 134.84 $\left(\mathrm{C}_{6} \mathrm{H}_{5}\right.$, ipso $), 128.48\left(\mathrm{C}_{6} \mathrm{H}_{5}\right.$, ortho and meta $)$, $127.97 \quad\left(\mathrm{C}_{6} \mathrm{H}_{5}, \quad\right.$ para $), 92.16 \quad(\mathrm{C}-2), 67.52$ $\left(\mathrm{COOC}_{2}\right), 63.80$ (C-6), 53.31 (C-5), 25.05 (C-3), 23.77 ppm (C-4).

\section{Hydrolysis of Polyesters}

A sample of polyester $(20 \mathrm{mg})$ was taken in each of several test tubes. A small amount of chloroform was added to dissolve the sample. By rotating the test tube and slowly evaporating the solvent, the bottom part of the inner wall of the test tube was coated with a thin film of the polyester. A phosphate buffer solution $(5 \mathrm{ml}, \mathrm{pH} 7.5)$ was added to each test tube. The test tubes were allowed to stand in a water bath thermostated at $30^{\circ} \mathrm{C}$. At specified intervals, one of the test tubes was taken out. The aqueous solution was separated from the insoluble polymer by decantation. The waterinsoluble polymer was washed with water, dried under vacuum, and weighed. The number average molecular weight of the waterinsoluble polymer was determined by vapor pressure osmometry. The separated aqueous solution was subjected to rotary evaporation to afford a white solid. The residue was extracted with acetone, and the acetone extract was subjected to rotary evaporation. The acetone-soluble material was analyzed by ${ }^{1} \mathrm{H}$ NMR.

Acknowledgment. Financial support from the Ministry of Edcation, Science, and Culture of Japan (Grants-in-Aid for Encouragement of Young Scientists No. 63470096 and for General Scientific Research No. 02650666) is greatly appreciated.

\section{REFERENCES}

1. R. A. Gross, C. M. McMello, R. W. Lenz, H. Brandl, and R. C. Fuller, Macromolecules, 22, 1106 (1989).

2. G. W. Huisman, O. Deleuw, G. Eggink, and B. Witholt, Appl. Environ. Microbiol., 55, 1949 (1989). 
3. Y. Doi and C. Abe, Macromolecules, 23, 3705 (1990).

4. Y. Doi, A. Segawa, and M. Kunioka, Int. J. Biol. Macromol., 12, 106 (1990).

5. G. W. Haywood, A. J. Anderson, and E. A. Dawes, Bactechnol. Lett., 11, 471 (1989).

6. M. Vert, Angew. Makromol. Chem., 166/167, 155 (1989).

7. E. Chellini and M. F. Saettone, J. Bioact. Compat. Polym., 3, 86 (1988).

8. R. Issa, A. Akelah, A. Rehab, R. Solaro, and E.
Chellini, J. Controlled Release, 13, 1 (1990).

9. S. Matsumura, S. Maeda, and Y. Yashikawa, Makromol. Chem., 191, 1269 (1990).

10. M. Okada, H. Sumitomo, M. Atsumi, H. K. Hall, Jr., and R. B. Ortega, Macromolecules, 19, 503 (1986).

11. M. Okada, H. Sumitomo, M. Atsumi, and H. K. Hall, Jr., Macromolecules, 20, 1199 (1987).

12. H. K. Hall, Jr., L. J. Carr, R. Kellman, and F. DeBlaue, J. Am. Chem. Soc., 96, 7265 (1974). 